\title{
THE INFLUENCE OF YOUTUBE ON ENGLISH VOCABULARY FOR CHILDREN 7-8 YEARS OLD
}

\author{
Getruida Nita Mozes \\ Polytechnic Negeri Nusa Utara, Tahuna, Indonesia \\ Email : mozesnita@gmail.com
}

\begin{abstract}
In the new norm era, children learn online from home. YouTube is used as a learning media to increase interest in learning English vocabulary. This qualitative descriptive study describes; how does YouTube affect the acquisition of English vocabulary and what is the impact of YouTube on the acquisition of English vocabulary. The study population was 7-8-year-old children. The research data is watching short English film and singing very simple English song from YouTube. The results of this study indicate that it is easier for children to pronounce and remember English words
\end{abstract}

Keywords: YouTube, vocabulary, 7-8 years old children

\begin{abstract}
ABSTRAK
Di masa new normal anak belajar dari rumah secara online. YouTube digunakan sebagai media pembelajaran untuk meningkatkan minat belajar kosa kata Bahasa Inggris. Penelitian deskriptif kualitatif ini mendeskripsikan; bagaimana pengaruh YouTube terhadap pemerolehan kosa kata Bahasa Inggris dan apa dampak dari YouTube terhadap perolehan kosa kata Bahasa Inggris. Populasi penelitian ini adalah anak umur 7-8 tahun. Data penelitian berupa kegiatan menonton cerita pendek dan menyanyikan lagu sangat sederhana Bahasa Inggris dari YouTube. Hasil dari penelitian ini menunjukkan bahwa anak lebih mudah untuk mengucapkan dan mengingat kata-kata bahasa Inggris,
\end{abstract}

Kata kunci: YouTube, kosa kata, anak umur 7-8 tahun

\section{INTRODUCTION}

One of the activities that must be carried out during the Pandemic Covid-19 is social distancing. For adults, this activity is not too difficult to do but for children 7-8 years old it is a punishment for them because one of the children's characteristics is playing and their immune system is also not too strong. Referring to this, the Minister of Education and Culture; Nadiem Anwar Makarim, B.A., M.B.A made a policy; All schools from early childhood education to a university must study online from home. This is very difficult and gives a hard impact on teachers, students, and parents.

For teachers, they must be more creative in choosing suitable materials and methods for online learning activities. And then, they must be skilful in using information technology applications to send and explain learning materials.

For learners who 7-8 years old, they must not play with their classmates and learn online from home. These activities obstruct children's social-emotional and cognitive expansion because through playing children can explore their world as a kid. According to Joan Freeman and Utami Munandar in Sabab Jalal (2013) defines that playing is an activity that helps children achieve their competence development of physical, intellectual, social, moral, and emotional. Playing can stimulate the expending of children's imagination because by playing children's emotional and intellectual abilities can develop rapidly. Santrock in Novi Mulyani (2013) reveals that the pattern of human development is generated by the relationship of several biological, cognitive, and socioemotional processes. 
Meanwhile, the impact for parents is that the cost of education is double than usual, starting from providing communication tools like cell phones or laptops, buying internet data for their children's online studying. And then, with limited time and knowledge having to act as a teacher to accompany and explain lessons given by the school (teacher). And the biggest impact for some parents, when they want their children to learn English.

With this problem, there was a socialization program for parents and children to introduce and explain how to use information technology to open YouTube English films and songs.

When children open these sites, there needs to be assistance from parents to direct children in choosing films, songs, and games, because YouTube has a negative impact; children can access adult features that can give a negative impact on the child's mental and character. Kartini Kartono (1979) said: children from 7-8 years have a desire to know the reality of objects and events to encourage children to research and conduct experiments.

Through video content on YouTube, children can learn English vocabulary with fun and natural like a process of their first language acquisition.

This study aims to describe how the influence of YouTube on children 7-8 years in acquiring foreign language vocabulary (English) and what is the impact of YouTube on the acquisition of English vocabulary.

\section{YouTube}

YouTube is a website that provides including video clips, TV show clips, music videos, short films and documentaries, audio recordings, movie trailers, live streams, and original short video content, and educational videos.

The advantages of YouTube include: (1) easy access from anywhere; (2) relatively inexpensive internet cost; (3) the video tells more detail and is easy to understand; and (4) YouTube is more applicable and inspirational.

However, one of the disadvantages of YouTube is for those who have a poor internet connection. Images will be blurry and take a long time to load the entire video. (YouTube Wikipedia)

\section{Influence YouTube for learning English vocabulary.}

Modern learning media such as YouTube are currently influencing children's curiosity and emotion because to operate it no needed basic and special knowledge. Anytime and anywhere it can be open as long as the internet network is not in trouble.

Pipit Utamil, at all (2018) said, YouTube is increasing demand in education. Its video content can be an option to be used as a medium for learning English vocabulary. And, YouTube can stimulate children's kinaesthetic learning style ability. Armstrong (2002: 3) argues that kinaesthetic intelligence or physical intelligence is intelligence when using it a person is able or skilled to use his body to perform movements such as running, dancing, building things, doing art and handicraft activities.

According to Thorndike, learning is a process of interaction between stimulus and response. A stimulus can train senses such as thoughts, feelings, or other things to learn something. Meanwhile, the response is the reaction of learners when their ability, emotion, thought, and feeling to are exercised to become habitual,

The activity of watching a video such as short films and simple English songs on YouTube as continuously can provide a stimulus for the children's mind to remember their vocabularies and sentences.

YouTube can create an atmosphere of learning activity for students to study and master English vocabulary through kinaesthetic learning style. With this 
learning style, students can be active. They can use their senses, physical, feeling, and thought while they are studying. With these activities, English vocabulary can be sent to long term memory as a knowledge.

\section{Characteristics of children 7-8 years old}

Children in this age are elementary school students who are psychologically in middle childhood. This period is a golden period for learning more than one language. According to Erikson, a psychological in SekolahDasar.net (2012), "language skills at this age are more developed by thinking about concrete operational concepts. The brain condition is still plastic and flexible so that language acquisition is easier. Children who learn foreign languages have more abilities in episodic memory tasks, learning sentences and words, and semantic memory, fluency in conveying messages, and categorizing. According to Oswald Kroh's theory in Kartini Kartono (1979), children who are 7-8 years old enter the synthesis-fantasy period. This means that all observations are an impression of totality/globality is still vague. Furthermore, these impressions are complemented by the association of children's fantasies. They love fairy tales, sage, myths, legends, tales, and fantasy stories.

Emmy Soekresno, Educational Consultant for Jerapah Kecil in Central Java PAUD (2015), explained, although as overall, brain functions work together and simultaneously, however, there are emphases or prime time for the brain. To learn a foreign language, for example, English, the prime time is 4-12 years old. At this age, learning with games and laughing, children can master and speak English.

\section{Vocabulary}

Talking about vocabulary means talking about an aspect of language called lexicology or the science of vocabulary. Lexicology or the science of vocabulary is the study of the words (I Nyoman Mardika; 2008). Vocabulary is a set of words that are owned by someone or a group, or be a part of a particular language.

As one component of language, vocabulary has an important role in human life to interact and to understand the user's culture and habits.

The other function of vocabulary is to be arranged or arranged in one sentence to develop speaking, listening, reading, and writing skills so that they can be understood by others. As a group of all the words that someone or everyone understands, they will be used and arranged into new sentences.

Since vocabulary is important in language learning, interesting activities, and a pleasant learning atmosphere are needed to influence and motivate children to master it, learning vocabulary must be taught easily and interestingly.

\section{RESEARCH METHODOLOGY}

This study uses qualitative research with the case study method. Followed by describing the results of the acquisition of English vocabulary.

The objectives that will be carried out are to describe how YouTube influences children 7-8 years old in acquiring English vocabulary and what is the impact of YouTube on the acquisition of English vocabulary. The data characteristics are descriptive and the emphasis is on process rather than the outcome. The population of this study was 5 children 7-8 years old who lived in the Akembuala village, Tahuna district, Sangihe Regency. The research data is the activity of watching short animated films and simple songs in English. This activity was carried out for 8 meetings. From the explanation of the analysis data 1) Observing, recording, and taking 
notes during the activity of watching animated films and short songs on YouTube. 2). The same movies and songs are still used to watch and sing for 2-3 meetings. This activity is to stimulate the child's brain to get used to hearing and saying the same words. 3). And given reinforcement by inviting to play while saying the words that have been heard and watched.

\section{RESULTS AND DISCUSSION}

During the New Normal (Pandemic Covid-19) schools were closed, tutoring centres and English language courses are also closed. To help children learn English naturally without depressing, feel bored, and stressed learn from home, English videos on YouTube can be an alternative to be used as a media for learning English vocabulary. Based on the results of research obtained on five (5) children 7-8 years old, there is an influence from watching English films and songs on YouTube. Vocabulary acquisition can be natural and easy if children acquire the language repeatedly to become familiar with them. Activities of watching English short films and sing simple English songs on YouTube become one of alternative 9hve.

There is a lot of English short film and English simple song can get on YouTube to help students gain English vocabulary. This study uses Gogo Adventure Part 1 film and the possessive pronoun song to become vocabulary lessons.

\section{Fun and interesting kinaesthetic learning activity}

To make words and sentences above can send to learners' long-term memory as knowledge. A roleplay is used as a technic to the held fun kinaesthetic learning activity. This roleplaying uses three dolls. Every doll is given a name like in the Gogo film "Gogo, Toni, and Jenni". Before the play will be begun, the Gogo film is played again to stimulus learners' minds and emotions about the character and sentences. They have to pronounce and repeat the sentences "My name is Gogo; Her name is Jenni; HisJenni is Toni" while they are watching. This part of this film will replay three times. Learners will be also trained to straighten their memory about negative, interrogative, question, and answer sentences without explaining their pattern. They are introduced to how these sentences can turn into positive, negative, and question sentences. After that, learners are invited to play and behave its characters

The procedure of this game is:

Every doll will be taken if its name is pronounced.

In this part, the target of the word is on "my", It is placed into an affirmative, negative, and the question (wh question) sentences; The Gogo doll is picked up and shook like someone is talking and introducing; "my name is Gogo"; "my name is not Tony"; "What is my name?" "My name is Gogo". After that, Jeni doll is taken; ", my name is Jenni", my name is not Ina", "what is my name?", "my name is Jenni". Then, Toni doll rises, and the activity run as the previous activities, Gogo doll is got while the learner pronounces Gogo's name and takes Toni doll while say "my name is not Toni". And then, to make learners understand the use of "question", the doll of Gogo is turned back and face to the other side of the other dolls, and say, "What is my name?". After that, Gogo faces to face with other dolls and pronounce "my name is Gogo". This activity run until all the doll have chanced

Learners act like a newcomer and shake the doll-like someone wants to introduce her/his self or someone else.

The focusing is on the word "her, his, my, and but". They will place into affirmative, negative, and interrogative sentences. Jeni doll is taken. The activity is like the previous activity when the Gogo doll has been taken. But to 
make learner get interrogative sentences naturally, the activity is.

The first chance is the Jeini doll. Jeni turns back to another side form Gogo and Toni. Then, Gogo asks Toni

Gogo: What is her name, Toni?

Toni: Her name is Ina.

After that, Jeni faces to them and say,

Jenni: My name is not Ina, but My name is Jenni".

The second chance is for Gogo. Gogo faces the other side of Toni and Jenni. Jenni asks Toni.

Jenni: What Is his name, Toni?

Toni: His name is Jullio.

After that, Gogo faces to them and say

Gogo: My name is not Jullio, but my name is Gogo

The third session is for Toni. Toni doll is walking pass to Gogo and Jenni. Then, Gogo asks Jenni.

Gogo: Is his name Amir, Jeini?

Jeini: No, His name is Anto.

After that, Toni stops, faces to them and says

Toni: My name is not Anto, but My name is Gogo.

Every doll must get a chance to introduce her/his self or someone else.

he targets word is the word "she, he her, his May. what and is. Targeting of the sentences are negative and yes/no question sentences. The film is on again. Learners are asked to dance and repeat the sentences. The film will be paused, while;

a. Picture of Gogo is pointing out, learners are asked.

$\mathrm{P}$ : Is he Toni?

L: No, he is not Toni

$\mathrm{P}$ : What is his name?

$\mathrm{L}$ : His name is Gogo

b. Picture of Jeini is shown, they are asked.

P: Is she Ina?

L: No, she is not Ina

$\mathrm{P}$ : What is her name?

$\mathrm{L}$ : Her name is Jenni

c. Picture Toni appears. Learners are asked:
$\mathrm{P}:$ Is he Anto?
L: No, he is not Anto
$\mathrm{P}$ : What is his name?
$\mathrm{L}$ : His name is Toni.

\section{Singing and Dancing, for Long-Term Memory.}

Some of the words will be erased from the mind if it is not needed and learners do not focus and concentration on them. To help learners keep concentration singing and dancing are using to attract their emotions and feeling to keep the vocabulary lessons as knowledge in long term memory. For that reason, sing and dance are using after learners have been watching film dan play role-play. To stimulate continuously their brain, they are asked to dance while they are singing "Possessive pronoun song". The lyric of this song is;

my name saya punya

(my name is my own name)

your name kamu punya

(your name is your own name)

her name dia punya

(her name is her own name)

his name dia punya

(his name is his own name)

While they are singing this song, they are asked to dance and find a picture of a girl and a boy. And then, they must point out and say their name. Then their family photo was taken and asked them to introduce his family. Next, a video of a simple song from YouTube plays the lyrics about introducing oneself (My name, your name, his / her name) and sing together. To provide reinforcement; learners are asking to introduce people around them. At the end of the activity, the children were taught how to search for movies and songs on YouTube, with lyrics about introducing themselves.

\section{CONCLUSION}

The role of parents is very important to help their children study English from home. And to company their children to 
open and watch videos on YouTube. The period of children who 7-8 years old can focus and remember English vocabulary if the activities are fun, varied, and moving. Watching a short English film and sing simple English songs on YouTube are using to help learners 7-8 years old master English vocabularies. A roleplaying is used as technic to make them study with kinaesthetic tyle and get fun vocabulary lessons. As a result of these activities, the English vocabulary can send to learners' long-term memory as their knowledge.

\section{ACKNOWLEDGEMENT}

Thank you to the parents of Nediva, Aliya, Kasih, Natanael, and Ica who can cooperate well and facilitate the research in the process of data retrieval.

\section{BIBLIOGRAPHY}

[1] Gage, N.L., \& Berliner, D. 1979. Educational Psychology.

Second Edition, Chicago: Rand Mc. Nally

[2] Brown, H D. (2000). Principles of Language Learning and Teaching. New York: Addison Wesley Longman Inc.

[3] Mardika, I Nyoman (2008); Pengembangan multimedia dalam pembelajaran kosa kata bahasa Inggris, core ac.uk

[4] Mulyani, Novi (2013), PERKEMBANGAN EMOSI DAN SOSIAL PADA ANAK USIA DINI, ejournal.iainpurwokerto.ac.id

[5] Utami Pipit (2018); "Video Moving Surveillance Yang Terintegrasi YouTube Menggunakan Raspberry”, Electronics, Informatics, and Vocational Education), DOI:10.21831/elinvo. v3i1.20797
[6] Anonimus

http://www.sekolahdasar.net/2012/ 11/anak-usia-sd-adalah-masaemasbelajar

[7] Anonimus https://sababjalal.wordpress.com/20 13/10/09/definisi-bermain-dan pentingnya-bermain-bagi-anak/

[8] Anonimus PaudJ ATENG (2015) https://www.paud.id/2015/04/penge rtian-masa-usia-emas-anak-goldenage.html

[9] Anonimus

https://mediaindonesia.com/read/de tail/330938-pandemi-mengubahpola-aktivitas-dan-belajar-anak.

[10] Anonimus https://www.dosenpendidikan.co.id /contoh-kosakata-bahasa-indonesia

[11] Anonimus https://kuwat.wordpress.com/artikel /pembelajaran-bahasa-kedua/

[12] Anonimus https://en.wikipedia.org/wiki/ YouTube 